\title{
OCHRONA

\section{EYE TRACKER JAKO PROSPOŁECZNE NARZĘDZIE ZARZĄDZANIA DZIEDZICTWEM URBANISTYCZNYM I ARCHITEKTONICZNYM}

\author{
RUSNAK Marta Alina ${ }^{1}$
}

${ }^{1}$ dr inż. arch. Marta Alina Rusnak, Wydział Architektury, Politechnika Wrocławska https://orcid.org/0000-0002-5639-5326

ABSTRAKT: Subiektywny punkt widzenia ekspertów często znajduje przełożenie na próby swobodnej reinterpretacji zapisów aktów prawnych. Uczestnikami „sporu o zabytek” mogą być zarówno inwestor, architekt, konserwatorzy, politycy, urzędnicy, jak i osoby trzecie - obywatele. W celu umożliwienia obiektywizacji podejmowanych decyzji, nawiazania dialogu opartego o wspólny punkt odniesienia lub danie społeczeństwu możliwości sprzeciwu, proponuję wykonywanie badań okulograficznych. Eye tracking (czyli okulografia) pozwala na śledzenie tego, w jaki sposób ludzie zapoznają się z prezentowanymi im przedmiotami. Dzięki rejestracji ruchów gałek ocznych dużej grupy obserwatorów możliwe jest zbadanie preferencji rządzących tym procesem jak i zaobserwowanie zmian wynikających $\mathrm{z}$ modyfikacji wprowadzanych $\mathrm{w}$ obrębie prezentowanego obiektu. $\mathrm{W}$ artykule zwięźle omówiono możliwe zastosowanie okulografów dla potrzeb różnorodnej, prawnej ochrony zabytków oraz wielowątkowego umożliwienia społeczeństwu uczestnictwa w tym procesie. W tekście umieszczono również argumenty za i przeciw wprowadzeniu takiej metody do powszechnego użytku. Dla czytelności wywodu zjawisko opisano w oparciu o przykład biblioteki wzniesionej w obrębie wrocławskiego Ostrowa Tumskiego. Celem artykułu nie jest podjęcie jednostkowej krytyki wspomnianej realizacji, a jedynie wyliczenie problemów, które mogłyby być sprawnie rozwiązane dzięki zupełnie nowemu podejściu badawczemu.

SŁOWA KLUCZE: Okulografia, zarządzanie zabytkami, rewitalizacja zabytków 


\section{Wstęp}

Wiele jest w Polsce sytuacji, w których jako obywatele mamy wątpliwości, czy w czasie rewitalizacji, adaptacji, remontu czy rozbudowy zabytek architektoniczny został faktycznie objęty najlepszą możliwą formą opieki. Zastrzeżenia wyrażane osobiście lub w formie pisemnej dotyczą różnych aspektów podejmowanych współcześnie interwencji: ochrony krajobrazu, prac związanych z elewacjami, bryłą i historycznymi wnętrzami czy rekonstruowanym detalem. Za przykład może posłużyć spór, który rozgorzał w odniesieniu do budowy Biblioteki Archidiecezjalnej (Ryc. 1) w obrębie objętego ochroną konserwatorską wrocławskiego Ostrowa Tumskiego i to ten przypadek będzie stanowił punkt odniesienia dla zawartych w niniejszym artykule rozważań na temat okulografów (eye trackerów) jako prospołecznego narzędzia sprawowania ochrony konserwatorskiej.

\section{Cel i zakres opracowania}

Celem artykułu jest przedstawienie badań eye trackingowych jako szansy na uspołecznienie i znaczącą obiektywizację procesu zarządzania zabytkami. Zamierzam przyjrzeć się bliżej zaletom i wadom takiego rozwiązania, a swój wywód przeprowadzę w oparciu o konkretny, wspomniany we wstępie przypadek. Ta analiza nie stanowi jednak krytyki jednego konkretnego obiektu, ale wierzę, że pozwoli zwrócić uwagę na pewne ogólne, systemowe niedociągnięcia w obecnym modelu zarządzania dziedzictwem architektonicznym i urbanistycznym.

\section{Opis analizowanej sytuacji}

Stronami sporu o wygląd nowo wzniesionego na Ostrowie Tumskim budynku usługowego, poza protestującymi aktywistami, częścią konserwatorów, architektów i urbanistów, stały się dwie grupy decyzyjne skupione wokół Wojewódzkiego Konserwatora Zabytków Barbary NowakObelindy oraz urzędników nominowanych przez Prezydenta Miasta Rafała Dutkiewicza, na których, zgodnie z prawem, scedowano obowiązek sprawowania opieki nad większością zabytków znajdujących się na terenie miasta.

Nowy budynek został wzniesiony w miejscu, zniszczonego podczas II wojny światowej, barokowego alumnatu. Nowy obiekt nawiązuje do istniejącej tu wcześniej budowli poprzez wykorzystane podziały, detale architektoniczne, a także dostosowanie się do jego niegdysiejszej skali. Jedyną, ale jak się okazuje istotną przyczyną sporu, była ostateczna kolorystyka dachu nowej biblioteki. Pierwotne wizualizacje przedstawiane $\mathrm{w}$ formie prezentacji multimedialnej do publicznych konsultacji ${ }^{1}$ nie wskazywały na to, iż projektant, dr inż. arch. Jerzy Gomółka, wraz z inwestorem, Archidiecezją Wrocławską, planują pokryć go w całości, zarówno elewacje, jak i połacie dachowe, biało-szarym kompozytem betonowym. Barbara Nowak-Obelinda negatywnie oceniła fakt zmiany kolorystyki obiektu względem wariantów prezentowanych powszechnie w mediach. Zapowiedziała wręcz kontrolę sposobu sprawowania opieki nad

\footnotetext{
$1 \quad$ Przykładem udostępnionych publicznie przez Archidiecezję Wrocławską materiałów jest dostępna w Internecie prezentacja https://www.youtube.com/watch?v=yfTMJGf0aiU.
} 
zabytkami przez Prezydenta Wrocławia i podległego mu Miejskiego Konserwatora Zabytków, Agatę Chmielowską. Nowak-Obelinda stwierdziła, iż „Plan zagospodarowania przestrzennego uznaje za najważniejsze wartości krajobrazowe terenu, wprowadza także zasadę rekonstrukcji historycznych obiektów.(...) Patrząc na Ostrów Tumski tak jasny budynek dezintegruje panoramę zabytkowego zespołu." Wojewódzka Konserwator nazwała powstający obiekt "fatamorganą", która zamiast dopełniać istniejący zespół zabytkowy, "ucieka" w zupełnie innym kierunku (E.W, 2016) ${ }^{2}$. Tej decyzji nie rozumieli również członkowie Towarzystwa Upiększania Miasta Wrocławia, w których imieniu wypowiadał się Przemysław Filar nazywając tę nieuzasadnioną jego zdaniem decyzję o pokryciu dachu perłowo-szarą dachówką „Disneylandem” zlokalizowanym w tak ważnym miejscu3.

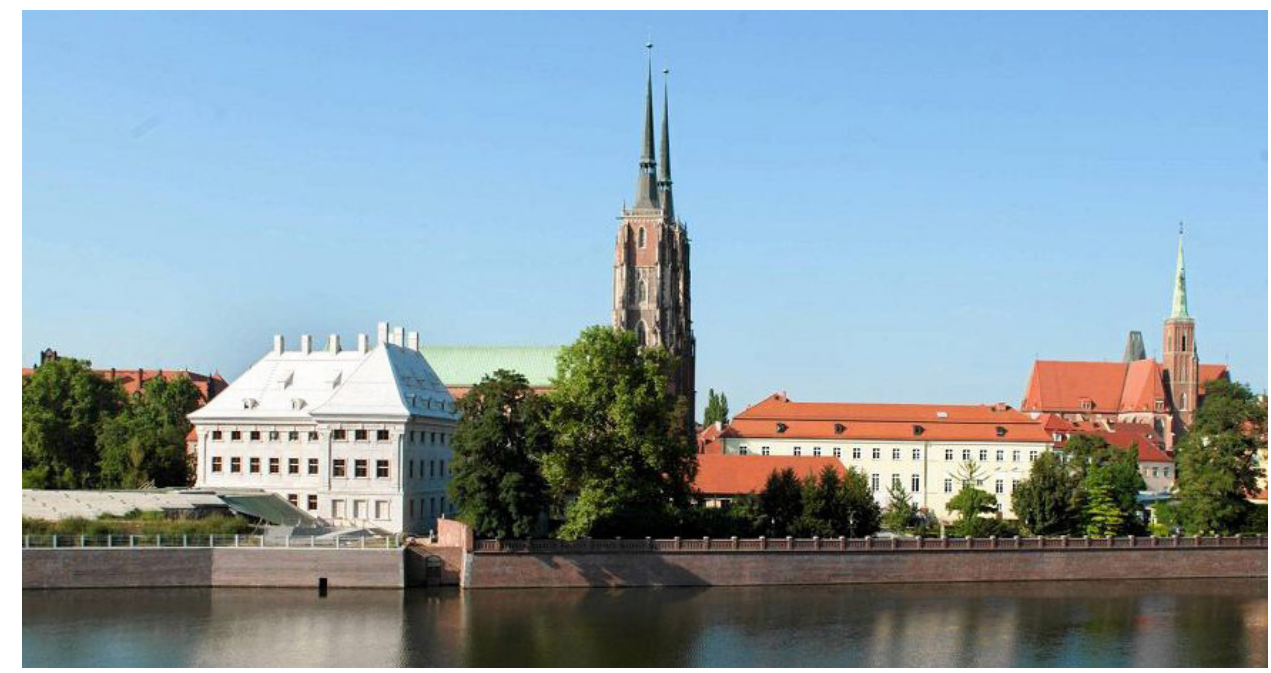

Ryc.1 Widok fragmentu Ostrowa Tumskiego we Wrocławiu z widocznym nowo wzniesionym budynkiem Biblioteki Archidiecezjalnej (fot. MR)

Odmienną opinię względem obiektu przedstawił Architekt Miasta Piotr Fokczyński. Wyraził on zdanie części architektów, którzy nie chcą być tylko autorami wiernych kopii i estetycznych imitacji. Dla tych twórców dalece uzasadnione wydaje się podejmowanie prób reinterpretacji przeszłości w obrębie szeroko rozumianego odtwarzania. W przeszłości w konsekwencji zniszczeń powstałych $\mathrm{w}$ wyniku katastrof naturalnych, działań wojennych, rewolucji społecznych, przewrotów politycznych niejednokrotnie następowały zwroty powodujące poszerzenie sposobu pojmowania i uzasadniania przyczyn podejmowania rekonstrukcji (Mager, 2015). To do tej różnorodności stosowanych praktyk zapewne odwoływał się Architekt

2 Uchwała NR XIIT/442/99 Rady Miejskiej Wrocławia dnia 21 października 1999 roku w sprawie uchwalenia miejscowego planu zagospodarowania przestrzennego obszaru - Ostrów Tumski, wyspy i Ogród Botaniczny we Wrocławiu.

3 Wypowiedź dostępna pod adresem http://www.radiowroclaw.pl/articles/view/47302/Perlowe-dachowki-czyli-kontrowersje-wokol-nowej-Biblioteki-Archidiecezji-Wroclawskiej, (dostęp dnia 28.12.2019) 
Miasta Wrocławia, gdy mówił: „Istnieją dwie drogi odtwarzania zabytków. Jedna zakłada daleko idące odtworzenie ich pierwotnego wyglądu, druga wplata elementy współczesne. Uważam, że w tym przypadku naśladownictwo wyglądałoby po prostu kiczowato" (E.W, 2016). Fokczyński nie poruszył jeszcze jednego aspektu ważnego z punktu widzenia przywracania dawnej formy architektonicznej. Nie do końca wiadomo bowiem, jakim materiałem pokryty był oryginalnie dach obiektu i jaką tonację nadano wówczas elewacjom. Kolorystyka obiektu wraz z biegiem lat przecież ulegała modyfikacjom, więc do której kolorystyki miałby się teoretycznie odwołać architekt?

\subsection{Zaobserwowane problemy prawne, polityczne i społeczne}

Studiując szczegółowo ustalenia obowiązującego na tym obszarze miejscowego planu zagospodarowania przestrzennego, można dostrzec, iż argumentacja Architekta Miasta mająca na celu obronę swobody ekspresji artystycznej jest w tym wypadku nietrafiona. Niezależnie od jednostkowych upodobań, w świetle obowiązującego prawa nie powinno się dopuścić do swobodnej retrowersji (Lubocka-Hoffmann, 2000). Możliwe, iż zapisy są zbyt restrykcyjne, a mimetyczna rekonstrukcja byłaby z punktu widzenia autentyczności zachowanego dziedzictwa nadużyciem, ale decydując się na realizację obiektu w takim wyjątkowym obszarze, zarówno inwestor jak i projektant muszą być gotowi na to, że swoboda ich działań będzie niezwykle ograniczona. Należy dodatkowo zauważyć, iż obiekt nawet przy zachowaniu tradycyjnej kolorystyki dachu i tak nie byłby wierną kopią, gdyż pozwolono na to, aby o czasie jego powstania świadczył współczesny materiał elewacji.

Przedstawiony problem, nie tylko sygnalizuje różnice $\mathrm{w}$ preferencjach estetycznych i prawdopodobnie dające o sobie znać obiekcje wykraczające poza architekturę, a leżące bliżej sfery polityczno-administracyjnej, ale powinien też wzbudzić ogólną refleksję nad sposobem zarządzania dziedzictwem architektonicznym w Polsce. Urzędy, które powinny funkcjonować obiektywnie, fachowo i bezstronnie, mogą budzić kontrowersje, ponieważ nie dbają o przestrzeganie zapisów prawa przez inwestorów. Taki stan rzeczy z pewnością nie budzi zaufania mieszkańców. Sytuacje, w których obywatele mają wątpliwości co do stopnia respektowania prawa, mogą sprawić, iż interesanci urzędów będą powątpiewać w fachowość podejmowanych tam decyzji. Mogą pojawiać się również oskarżycielskie głosy sugerujące, że zwykły obywatel nie ma takich samych praw i nie jest w stanie wywalczyć dla siebie równie wiele, co wpływowa instytucja, tu religijna, czy znany artysta - architekt.

Innym istotnym aspektem zarysowanej sytuacji jest skrywanie przed opinią publiczną oraz częścią administracji, prawdziwego oblicza planowanych rozwiązań. Świadome wprowadzanie współobywateli w błąd i manipulowanie opinią publiczną jest moralnie wątpliwe. Rzecznik Archidiecezji ks. Rafał Kowalski, opowiadał dziennikarzowi Gazety Wrocławskiej o tym iż od samego początku „biblioteka nie miała imitować osiemnastowiecznego budynku, ale wskazywać na współczesny czas powstania... już na etapie tworzenia projektu, w porozumieniu z Architektem Miejskim oraz Miejską Konserwator Zabytków - podjęto decyzję, by biblioteka nie była w żaden sposób barwiona. Ma zatem naturalną fakturę materiału, z którego wykonano elewację. Podobne założenie dotyczyło dachu." Wypowiedź ta jest jednak sprzeczna ze stanem 
faktycznym, gdyż prezentowane materiały prasowe, dostępne przed rozpoczęciem realizacji, pokazywały budynek o dachu zabarwionym na czerwono.

Warto zadać pytanie, czemu służą prezentowane publicznie wizualizacje takich obiektów. Uzasadniona wydaje się teza, iż mieszkańcy miasta powinni mieć prawo do wypowiedzenia się na temat prawdziwego oblicza zmian, skoro „w stale zmieniającym się miejskim spektaklu, każdy jest przecież aktorem a przynajmniej widzem" (Kłosek-Kozłowska, 2017). Jest to szczególnie istotne w obrębie miejsca tak ważnego pod względem kulturowym, gdzie obywatele budujący społeczność mogą stawać się „bioczujnikami” (Aa Chun, \& Artigas, 2015) pozwalającymi na diagnozę planowanych zmian. Jak budować wiarę ludzi we własną sprawczość (Stawasz, \& Sikora-Fernandez, 2016), skoro jeśli nawet zabraliby głos w tej sprawie, to okazałoby się, że są zwodzeni, bo ich opinia odnosiłaby się do czegoś, co być może nigdy nie miało zostać w takiej formie zrealizowane.

Czy istnieje szansa społecznej kontroli w takich sytuacjach? Czy środowisko konserwatorskie pozostaje bezradne wobec tego rodzaju nadużyć? Czy architekci i inwestorzy będą mieli kiedykolwiek szansę udowodnić swoje racje? Nie będzie to możliwe, póki nie zaczniemy dysponować narzędziami umożliwiającymi zobiektywizowaną ocenę wpływu współczesnych przekształceń na odbiór zabytkowego otoczenia. Wierzę, że odpowiedź dla tego problemu może do pewnego stopnia stanowić urządzenie znane jako okulograf (eye tracker).

\section{Czym jest wideookulograf}

Okulografy, inaczej eye trackery, są to rozmaite urządzenia służące śledzeniu sposobu, w jaki ludzie poruszają gałkami ocznymi. Wideookulografy są tymi najbardziej rozpowszechnionymi wśród współczesnych badaczy, gdyż są bezinwazyjne. Przy pomocy kilku odpowiednio dobranych wiązek światła podczerwonego wysyłanych w kierunku oczu obserwatora, okulograf może odnotować w jakim oddaleniu od środka źrenicy powstają jego odbicia. Tak ustalana jest oś pola widzenia i miejsce, w które patrzy uczestnicząca w testach osoba. Istnieją trzy grupy tych urządzeń. Pierwsza służy do badania obrazów wyświetlanych na ekranie monitora (statycznych - jak zdjęcia, bądź dynamicznych - jak filmy czy strony internetowe) (Rusnak, \& Szewczyk, 2018). Kolejną grupą są urządzenia zakładane na głowę badanego, który może poruszać się $\mathrm{w}$ analizowanej przestrzeni (Rusnak, \& Ramus, 2019). Trzeci rodzaj okulografów służy do obserwacji obiektów wyświetlanych w ramach wirtualnej rzeczywistości ${ }^{4}$. Niezależnie od typu eye trackera cały proces poznawczy zapisywany jest jako seria fiksacji (fixation) - zatrzymań wzroku - oraz sakkad (saccade) - momentów przenoszenia uwagi wizualnej z jednego miejsca na drugie (Soluch, \& Tarnowski, 2013).

Dzięki matematycznemu przetworzeniu zapisanych danych biometrycznych można poznać zarówno preferencje konkretnej osoby, jak i zbadać tendencje rządzące większą grupą obserwatorów. Te skłonności można opisać, podając uśredniony czas trwania fiksacji (fixation

4 Zobacz również: Jak patrzymy na Architekturę? Badania z użyciem eye trackera i gogli VR, https://pwr.edu. pl/uczelnia/aktualnosci/jak-patrzymy-na-architekture-badania-z-uzyciem-eye-trackera-i-gogli-vr-10809.html. 
duration), łączny czas trwania serii fiksacji (total fixation duration), liczbę fiksacji (fixation count) w wyznaczonym obszarze zainteresowania wizualnego (area of interest). W wielu sytuacjach poznawczych istotna może być również kolejność patrzenia na rozpoznawane elementy prezentowane $\mathrm{w}$ czasie badań, co charakteryzuje uśredniony czas, po którym obserwatorzy wykonują pierwszą fiksację na oglądanym przedmiocie (time to first fixation). Do bardziej zaawansowanych testów można uszczegóławiać analizy, podając kolejne parametry procesu poznawczego (Holmqvist et al., 2011) (Duchowski, 2017).

W zależności od celu prowadzonych obserwacji badacze zmuszeni są do przygotowania odpowiedniej metodologii dla swoich testów. Powinni każdorazowo zdecydować, jaka będzie wielkość grupy badawczej, kto i z jakich względów nie może uczestniczyć w testach, jak nie sugerować badanym sposobu w jaki mają patrzeć na prezentowane im obrazy, oraz czy rejestracja okulograficzna wymaga uzupełnienia o jakąś inną formę badań np. ankietyzację czy rejestrację tętna i ciśnienia krwi. Najczęściej wymaga to posiadania dużego doświadczenia lub konsultacji z psychologiem, socjologiem i/lub bioinżynierem. Zgodnie z celem badań prowadzący testy decydują także o tym, ile i jakich stref zainteresowania wizualnego należy wyodrębnić w obszarze badanego bodźca wizualnego i jak te obszary diagnozować.

\subsection{Okulogaf jako nowa opcja zarządzania}

W żadnym kraju nie zdecydowano się jeszcze na systemowe wykorzystanie okulografów jako narzędzi służących do udoskonalania zarządzania przestrzenią zurbanizowaną. Moją propozycją jest uspołecznienie i obiektywizacja procesu zarządzania dziedzictwem poprzez poszerzenie wachlarzabadańkonserwatorskichobadania okulograficzne. Omawianątechnologięwykorzystuje się wszędzie tam, gdzie wiedza o procesie poznawczym i wynikające z tej wiedzy zmiany mogą generować zyski, zoptymalizować procesy lub zminimalizować straty. W przypadku opieki nad zabytkami też tak może się stać. W dzisiejszym świecie wydaje się koniecznym, by szybciej przyswajać nowoczesne technologie diagnostyczne, otwierając się tym samym na społeczeństwo, pozwalając obywatelom na współuczestnictwo w zarządzaniu dziedzictwem kulturalnym. W obrębie przestrzeni publicznej miast oferta funkcjonalna i kulturalna musi być coraz częściej i lepiej dostosowywana do ulegającego szybkim transformacjom rynku turystycznego i ewoluujących potrzeb mieszkańców (Chhabra, 2015). Społeczeństwo obywatelskie powinno wymagać od swoich władz większej transparentności w procesie podejmowania najważniejszych $\mathrm{z}$ ich punktu widzenia decyzji. Zdaniem wielu badaczy wdrażanie złożonych, częściowo zautomatyzowanych systemów diagnozowania potrzeb społecznych (Aa Chun, \& Artigas, 2015), (Stawasz, \& Sikora-Fernandez, 2016), (Grabowska, Pancewicz, \& Sagan, 2015) szczególnie w obrębie miast o silnej tożsamości historycznej, wydaje się w perspektywie najbliższych 1015 lat nieuniknione. Okulografy zaś oferują możliwość pozyskiwania dotychczas nieosiągalnego rodzaju danych, które mogłyby mieć wpływ na wypracowywanie strategii zrównoważonego rozwoju zabytkowych kompleksów urbanistycznych, jak i na osiąganie kompromisów w czasie procesu rewitalizacji, adaptacji i rozbudowy pojedynczych budynków. Wydaje się, że środowisko konserwatorskie skorzystałoby na sięgnięciu po współczesne osiągnięcia $\mathrm{w}$ dziedzinie marketingu, w tym po okulografy (Parowicz, 2018). 


\section{Okulograficzna opieka konserwatorska}

Najprostszym sposobem przeprowadzenia badań, w wyniku których poznamy preferencje wizualne obserwatorów jest wykorzystanie okulografu stacjonarnego i przebadanie przygotowanych płaskich bodźców wizualnych w postaci zdjęć, wizualizacji i fotomontaży. Należałoby zastanowić się jednak jaki jest cel i najbardziej dogodny moment na prowadzenie takich badań.

\subsection{Interwencyjne badania kontrolne}

Pierwszą możliwością jest rozstrzyganie już zaistniałego konfliktu. W tym wariancie badań okulograficznych podstawowym pytaniem byłoby to, czy nowy budynek narusza zapisy miejscowego planu zagospodarowania (MPZP) lub innych wytycznych konserwatorskich. Powracając do opisanego przykładowego sporu, pytanie należałoby doprecyzować: czy poprzez zmianękolorystyki pokrycia dachowego nowy budynek staje się elementem dysharmonizującym zabytkowy krajobraz. W przywołanej uchwale Rady Miejskiej (Uchwała NR XIIT/442/99 Rady Miejskiej Wrocławia dnia 21 października 1999 roku w sprawie uchwalenia miejscowego planu zagospodarowania przestrzennego obszaru - Ostrów Tumski, wyspy i Ogród Botaniczny we Wrocławiu) wyraźnie zaznaczono iż ochronie podlega widok na Ostrów Tumski z Bastionu Ceglarskiego (\$11.2.1). Wskazano także na konieczność ochrony dominant zabytkowego zespołu urbanistycznego, nakazując wykonywanie szczegółowych studiów krajobrazowych dla rekonstruowanych obiektów (\$12.11). Aby obiektywnie sprawdzić, czy te zapisy prawa zostały naruszone wystarczyłoby z przeciwległego brzegu Odry, ze wzniesienia Bastionu Ceglarskiego wykonać zdjęcie obejmujące swym kadrem nową Bibliotekę Archidiecezjalną wraz ze sporym fragmentem jej urbanistycznego otoczenia (Ryc.1). Ilustrację należałoby następnie pokazać odpowiednio licznej grupie osób, najlepiej nie posiadających edukacji zawodowej (w zakresie architektury, urbanistyki, konserwacji, czy historii sztuki) wpływającej na postrzeganie krajobrazu kulturowego. Należałoby poważnie rozważyć, czy ilustracje powinny być pokazywane osobom, które dobrze znają dane miasto, ponieważ mogłyby one zwracać zbyt dużą uwagę na wprowadzone zmiany odbiegające od widoków, do których podziwiania przywykli. Prowadząc rejestracje okulograficzne każdorazowo należałoby również zastanowić się nad nadaniem obserwatorom jednorodnego celu poprzez wymyślenie wraz z psychologiem fałszywego zadania, które realizowaliby uczestniczący w testach wolontariusze. Dawałoby to gwarancję, że wszyscy uczestnicy badań prowadzonych na dowolnym etapie testów, będą patrzeć na prezentowany materiał graficzny $\mathrm{z}$ podobną motywacją. Jedynie ujednolicona i starannie opisana metodologia byłaby gwarantem tego, iż dane dałoby się uznać za miarodajne oraz możliwe do porównania czy ewentualnego powtórzenia. Dlatego każdorazowo należałoby podawać parametry zastosowanego okulografu (np. częstotliwość próbkowania), sposób prowadzenia osobniczej kalibracji urządzenia, czas prowadzonej rejestracji, liczbę oraz rodzaj ilustracji towarzyszących badaniu, parametry monitora, na którym wyświetlano eksperyment. Należałoby również dołączyć wzorzec ilustracji gdyż istotna jest jej rozdzielczość, proporcje, kontrast, jasność i kolorystyka. 
Niewielką liczbę danych dla omawianego w artykule przykładu udało mi się zgromadzić przy okazji prowadzenia innych testów okulograficznych, w których zdjęcie Ostrowa Tumskiego (Ryc. 1) z widoczną bryłą nowej biblioteki, posłużyło mi jako ilustracja przekładkowa w prezentacji. Metodologia badania nie była przemyślana pod kątem określenia hierarchii prezentowanego bodźca, np. zastanawiano się wtedy precyzyjnie nad zakresem kadru, a profil obserwatorów nie został przeanalizowany pod względem celu prowadzonych obecnie teoretycznych rozważań, np. byli to mieszkańcy miasta. Grupa badawcza była dość liczna (ponad 70 osób), ale czas prezentacji bodźców został ograniczony do 8 sekund zgodnie z celem prowadzonych wtedy rozważań (Rusnak, Fikus, \& Szewczyk, 2018). Z przyczyny niedostosowania metodologii do celu jaki opisuję $\mathrm{w}$ tym artykule, dane umieszczone $\mathrm{w}$ tabeli nie powinny być odbierane jako rozstrzygające, uznałam jednak, iż stanowią one cenny materiał poglądowy. W oparciu o konkretny przykład i przyporządkowane do niego wartości liczbowe łatwiej będzie zarysować ideę wykorzystania okulografu dla potrzeb zarządzania dziedzictwem.

\subsubsection{Propozycja nr 1 - Analiza czasu patrzenia}

Po zgromadzeniu danych najbardziej uniwersalną metodą analityczną byłoby w tym przypadku wykonanie waloryzacji, zgodnie z którą wyłoniono by strefy zainteresowania wizualnego (AOI) odpowiadające najważniejszym chronionym elementom krajobrazu, oraz określenie średniego czasu patrzenia na nie. W przedstawionym przykładzie byłyby to dominanty tego frontu wodnego: katedra pod wezwaniem Świętego Jana Chrzciciela oraz kościół Świętego Krzyża. Trzecią analizowaną strefą wizualną powinno być pole AOI odpowiadające widokowi wznoszonego obiektu (Ryc. 2). Dla tak wyznaczonych stref zainteresowania wizualnego otrzymane zostały dane, które umieszczono w tabelach (Tab. 1 i 2).

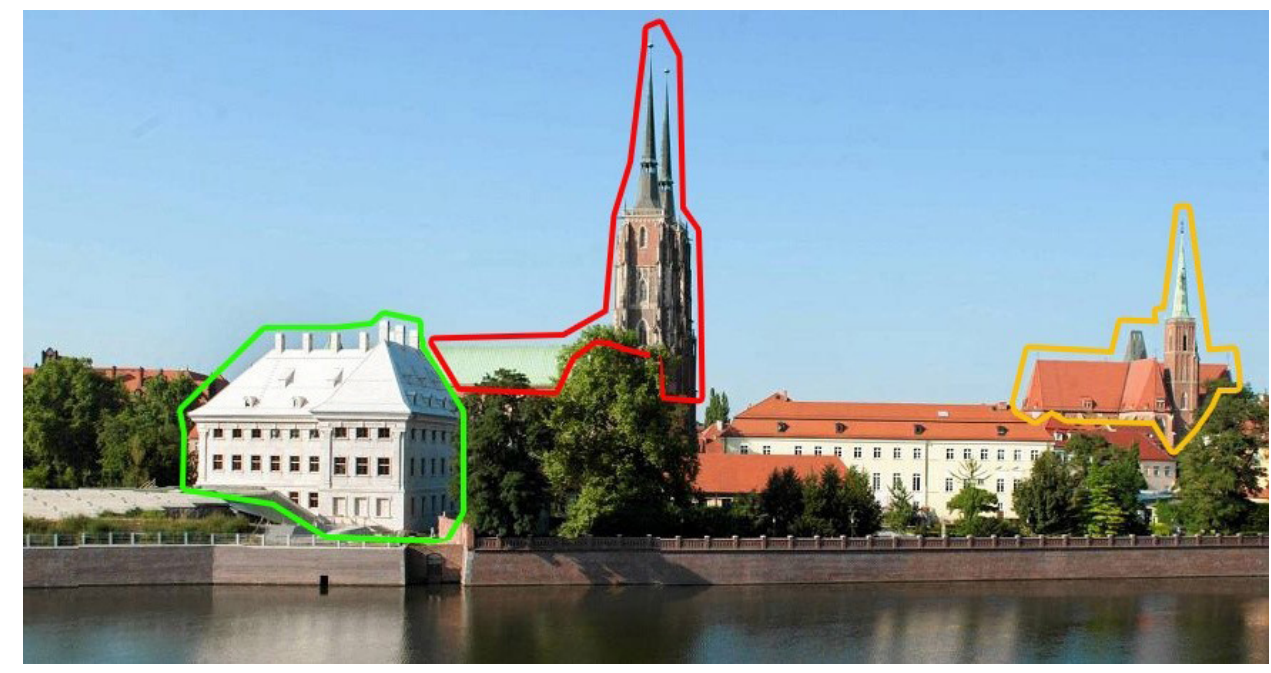

Ryc. 2 Dyspozycja stref zainteresowania wizualnego (AOI) na zdjęciu fragmentu Ostrowa Tumskiego we Wrocławiu (MR) 


\begin{tabular}{|c|c|c|c|c|c|}
\hline Przykład & $\begin{array}{l}\text { Czerwone } \\
\text { AOI } \\
\text { Katedry }\end{array}$ & $\begin{array}{c}\text { Żółte } \\
\text { AOI } \\
\text { Kościół } \\
\text { Św. Krzyża }\end{array}$ & $\begin{array}{c}\Sigma \\
\text { Czerwone } \\
\text { i żółte } \\
\text { AOI } \\
\text { Katedry i } \\
\text { Kościoła } \\
\text { Św.Krzyża }\end{array}$ & $\begin{array}{c}\text { Zielone } \\
\text { AOI } \\
\text { Nowej } \\
\text { Biblioteki } \\
\text { Archidiece- } \\
\text { zjalnej }\end{array}$ & $\begin{array}{l}\text { Pozostałe } \\
\text { elementy } \\
\text { Ilustracji }\end{array}$ \\
\hline $\begin{array}{l}\text { Sredni czas trwania } \\
\text { wszystkich fiksacji }\end{array}$ & $30,1 \%$ & $9,6 \%$ & $39,7 \%$ & $42,2 \%$ & $13 \%$ \\
\hline $\begin{array}{l}\text { Zakres jednostko- } \\
\text { wych wyników } \\
\text { (max i min) }\end{array}$ & $23,2-37,1 \%$ & $5,3-13 \%$ & $27,5-50,1 \%$ & $32,1-59,8 \%$ & $7,5-18 \%$ \\
\hline
\end{tabular}

Tab. 1 Analiza czasu poświęcanego na zapoznanie się z wyznaczonymi polami uwagi wizualnej (AOI) (MR)

Pomimo iż danych nie można uznać za rozstrzygające, to zwracają uwagę niekorzystne tendencje, jakie ukazały te wstępne testy. Obserwatorzy poświęcali przeciętnie od 32,1 do 59,8\% czasu na wodzenie wzrokiem po bryle nowego obiektu, podczas gdy elementy mające stanowić dominanty statystycznie otrzymały znacznie mniej uwagi (Tab. 1).

Zaburzenie hierarchii, wprowadzone $\mathrm{w}$ ten krajobraz przez nowy element, jest najlepiej widoczne, gdy porównamy przeciętny czas poświęcony na wodzenie wzrokiem po obydwu dominantach $(3,2 \mathrm{~s}-39,7 \%) \mathrm{z}$ wynikiem otrzymanym dla bryły nowej biblioteki $(3,3 \mathrm{~s}-42,2 \%)$. Uwaga poświęcana na zapoznanie się z wyglądem dwóch historycznych dominant okazała się mniejsza od uwagi poświęcanej nowej Bibliotece Archidiecezjalej także w odniesieniu do zakresu zarejestrowanych wyników wszystkich uczestników badania wynoszącego od 27,5\% do $50,1 \%$ czasu patrzenia na prezentowany bodziec wizualny.

Co ważne, nowe obiekty architektoniczne, muszą być zauważane w krajobrazie miasta, a zatrzymanie wzroku na ich bryłach jest konieczne. To może mieć wpływ na sukces znajdującej się w jego wnętrzu funkcji. Niepokój budzi jednak sytuacja, gdy czas poświęcany na wodzenie wzrokiem po nowo wzniesionym obiekcie jednoznacznie dominuje cały proces zapoznawania się z tak ważnym krajobrazem kulturowym. 


\subsubsection{Propozycja 2 - Zasada preferowanej kolejności patrzenia}

Inną, jeszcze prostszą metodą numerycznego wyznaczenia zasad interwencji w zabytkowym otoczeniu byłoby, w niektórych przypadkach, określenie preferowanej kolejności patrzenia na elementy budujące daną kompozycję. Ponownie odwołując się do zrekonstruowanego widoku wrocławskiego Ostrowa Tumskiego, katedra powinna być najprawdopodobniej pierwszym zauważanym elementem, a przypuszczalnie następna w kolejności powinna być wieża kościoła Świętego Krzyża. To sygnalizowałoby, jakie elementy są wizualnymi dominantami tego krajobrazu kulturowego. Gdyby dodany na ilustracji projektowany element zaburzał tę chronologię, to z pewnością nie powinien zostać zrealizowany w prezentowanej formie. Pozyskanie tego rodzaju danych dzięki testom eye trackingowym także jest możliwe (tabela nr2).

\begin{tabular}{|l|c|c|c|}
\hline Przykład & $\begin{array}{c}\text { AOI } \\
\text { Katedry }\end{array}$ & $\begin{array}{c}\text { AOI } \\
\text { Kościoła } \\
\text { Świętego Krzyża }\end{array}$ & $\begin{array}{c}\text { AOI } \\
\text { Nowej Biblioteki } \\
\text { Archidiecezjalnej }\end{array}$ \\
\hline $\begin{array}{l}\text { Średni czas do } \\
\text { pierwszej wizyty }\end{array}$ & $1,3 \mathrm{~s}$ & $3,7 \mathrm{~s}$ & $1,2 \mathrm{~s}$ \\
\hline Średnia liczba rewizyt & 2,1 razy & 1,4 razy & 3,5 razy \\
\hline
\end{tabular}

Tab. 2 Tabela ukazująca preferowaną chronologię zapoznania się z konkretnymi obszarami atencji wizualnej (AOI) (MR)

Analizując tabelę, widzimy, iż najliczniejsza grupa widzów w pierwszej kolejności patrzyła nie na katedrę, a na budynek będący retrowersją dawnego alumnatu, co świadczy o zaburzeniu opisanej powyżej chronologii. Dodatkowo bryła nowej biblioteki była oglądana częściej niż pozostałe elementy przygotowanego do testów bodźca wizualnego. Widzowie w ciągu 8 sekund patrzyli średnio 2 razy na wieże katedry podczas, gdy nowy budynek przyciągał wzrok zazwyczaj 3 lub 4 krotnie.

Oczywiście obie metody, dotyczące analizy czasu patrzenia i chronologii procesu poznawczego, mogą współistnieć i nawzajem się dopełniać.

\section{Badania na etapie tworzenia koncepcji}

Testy okulograficzne mogłyby być wykorzystywane także na wcześniejszym etapie prac projektowych. Możnaby sięgać po nie w czasie prowadzenia konsultacji inwestora i architekta z konserwatorem. W tym wypadku przebadanie wariantów kolorystycznych pozwoliłoby na uzyskanie obiektywnych dla obydwu stron wytycznych. Konserwator w przypadku wątpliwości mógłby zlecić wykonanie wizualizacji z różnymi wariantami kolorystycznymi pokrycia dachu. Poza przedłożonym najbardziej śmiałym wariantem należałoby wykonać ilustracje pokazujące budynek z dachem w kolorze ceglastym (Ryc. 4), a być może i takim imitującym połać pokrytą patynowaną miedzią (Ryc. 3). Zestawienie danych uzyskanych w trzech niezależnych badaniach 
z trzema różnymi kolorystykami dałoby lepsze wyobrażenie, na ile kolor dachu wpływa na odbiór zabytkowego krajobrazu.
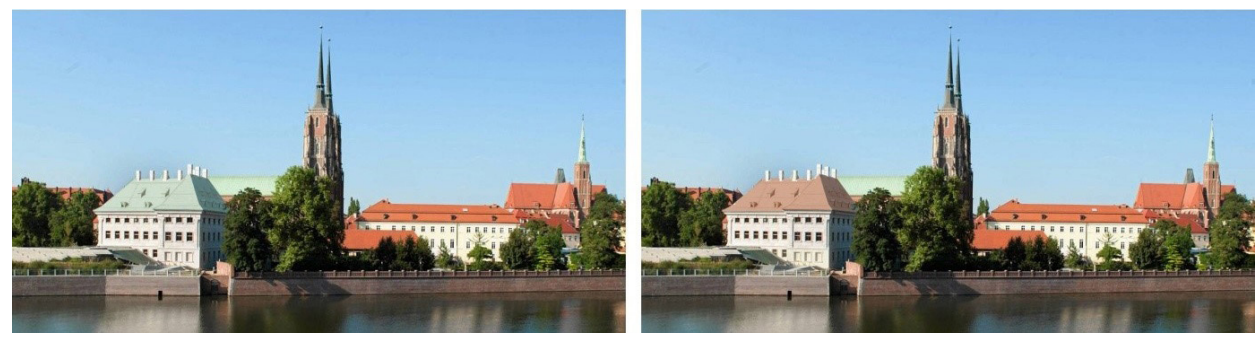

Ryc. 3, Ryc. 4 Fotomontaże wykonane na zdjęciach fragmentu Ostrowa Tumskiego (MR)

\section{Badania na etapie studiów krajobrazowych i uchwalania wytycznych konserwatorskich}

Badania okulograficzne mogą stanowić nie tylko szansę na rozstrzyganie sporów, ale także na tworzenie procedur prawno-administracyjnych opartych o obiektywne przesłanki. Testy okulograficzne przeprowadzone przez wyznaczonych i przeszkolonych do tego celu urzędników mogłyby ułatwić stworzenie obiektywnie istotnych i zasadnych norm regulujących konserwację danej przestrzeni lub konkretnego obiektu. Jest to jednak wyidealizowana sytuacja, niepozbawiona wad. Wykonanie testów odnoszących się do percepcji wizualnej wszystkich chronionych obszarów byłoby bardzo kosztowne dla budżetu państwa/województwa/miasta. Nawet w przypadku gdyby takim obowiązkiem objąć tylko najważniejsze zabytki i kompleksy urbanistyczne, konieczne byłoby przebadanie wielu setek bodźców wizualnych, a wyniki tych testów należałoby następnie zinterpretowaći uwzględnić w programach opieki konserwatorskiej, co generowałoby gigantyczne koszty i wymagałoby ogromnych nakładów pracy.

Wytyczne do interpretacji badań okulograficznych, na etapie sporządzania miejscowych planów zagospodarowania, można by było zapisywać dzięki analizom kompozycji wykonywanych zgodnie $\mathrm{z}$ dotychczasową praktyką. We wspominanej uchwale znajdował się zapis, iż dominantami w tym wrocławskim krajobrazie są widoczne bryły kościołów. Można by było dodać, iż najważniejszym elementem kompozycji jest katedra. Takie sformułowania z łatwością dałoby się przełożyć na parametry wizualne:

1. Na oglądanie wież katedry i kościołów obserwatorzy powinni poświęcać najwięcej czasu.

2. Wieże kościelne powinny być elementami, które w widoku frontu wodnego obserwowanego z wyznaczonych punktów przeciwległego nabrzeża jako pierwsze przyciągają wzrok.

3. Na inne pojedyncze obiekty kompozycji urbanistycznej obserwatorzy nie powinni patrzeć szybciej i częściej niż na wieże katedry.

Dodatkowo należałoby precyzyjnie określić zakres objętych ochroną konserwatorską widoków. Przykładowo do planu miejscowego można by wprowadzić zapis, iż elementem analizy okulograficznej może się stać dowolny charakterystyczny punkt widokowy, wybrany przez Konserwatora Wojewódzkiego / Miejskiego, leżący na południowym brzegu Odry pomiędzy mostem Grunwaldzkim a mostem Piaskowym lub na bulwarze spacerowym na Wyspie Piaskowej. 


\section{Pozostałe argumenty za i przeciw wprowadzeniu badań okulograficznych do systemu ochrony zabytków}

W tekście wspomniano już o konieczności każdorazowego dostosowania metodologii prowadzenia testów do konkretnej sytuacji poznawczej. W kolejnych podpunktach omówione będą inne aspekty mogące budzić wątpliwości.

\subsection{Stan zachowania zabytkowego krajobrazu}

Otoczenie urbanistyczne i naturalne ulega ciągłym przeobrażeniom. Zmienne są przecież warunki oświetlenia, zarówno naturalnego jak i sztucznego. Dodatkowo elewacje wraz z upływającym czasem ciemnieją, bądź nabierają blasku po oczyszczeniu. Drzewa rosną, są wywracane przez wichury lub wycinane. To aspekty, które w różnym stopniu modyfikują percepcję zachowanego dziedzictwa.

Moim zdaniem istnieją okoliczności, które uniemożliwiają proste zbadanie relacji współczesnych interwencji architektonicznych i zabytkowego otoczenia. Jedną z nich jest sytuacja, w której nowa kubatura wznoszona jest w bardzo zaniedbanej, choć zabytkowej okolicy. W takim przypadku nowy obiekt będzie najprawdopodobniej tym najsilniej przyciągającym uwagę - nie ze względu na niedostosowanie do zasad chronionej kompozycji, ale z powodu swojej inności. Zgodnie z treściami zawartymi miedzy innymi w publikacjach Ersta Gombricha, wzrok kierowany jest najszybciej „w miejsca nieregularności” (Gombrich,1979). Gdy odejście od jakiejś reguły jest zbyt duże, element wyłamujący się z niej będzie zauważany szybciej. O odmienności nowego tworu świadczyłby w tym wypadku jego schludny wygląd. Czy oznacza to, że takie okulograficzne studium uwagi poświęcanej zaniedbanemu układowi poddanemu rekompozycji należałoby wykonać dla wizualizacji symulującej docelowy wygląd wszystkich wchodzących w jego zakres zabytków? Przygotowanie bodźców dla takich badań byłoby bardzo czasochłonne.

Przytoczona w artykule sytuacja nie budzi takich wątpliwości, gdyż zabytki wrocławskiego Ostrowa Tumskiego, a także ich otoczenie, są bardzo zadbane.

\subsection{Laicki i ekspercki punkt widzenia}

Nie brakuje wśród środowiska eksperckiego - konserwatorów i architektów - osób pełnych rezerwy względem wykorzystania eye trackerów. Część z nich obawia się prawdopodobnie podważenia ich kompetencji albo pozycji naukowego autorytetu. Inni wyrażają wątpliwość, czy równie ważne kwestie estetyczne powinny być współrozstrzygane przez niewyedukowane w tej dziedzinie społeczeństwo. Istnieje obawa, że promowane będą projekty pospolite lub wręcz w złym guście. $Z$ drugiej strony podobne ryzyko można ograniczyć, o ile o doborze bodźców wizualnych i procedurze ich przygotowania będą decydować eksperci lub uczestniczące w sporze strony, a także psycholodzy kontrolujący to, czy metodologia badania jest możliwie neutralna względem zadania, jakiemu ma służyć. Dzięki takiej laickiej opinii można by uzyskać informację, który aspekt decyzji profesjonalistów budzi ewentualne kontrowersje i wymaga ponownego przepracowania albo starannego uzasadnienia. Można założyć, iż okulografia 
umożliwiłaby unikanie „krańcowości” (Gołaszewska, 1984). Wiadomo przecież, iż system wartości ekspertów może być skrajnie różny od motywacji rządzących resztą społeczeństwa (Ingarden, 1970) (Murzyn, 2014).

Badania okulograficzne wprowadzone do systemu zarządzania zabytkami byłyby prodemokratyczną modyfikacją prawa, urzeczywistniającą nowocześnie wykonywane konsultacje społeczne (crowdsourcing), ale także promującą otwartość ekspertów na inny sposób myślenia i postrzegania rzeczywistości. Zwrócenie się ku „mądrości tłumu” i masscolaboration, czyli współpraca $\mathrm{z}$ osobami, a być może i organizacjami spoza formalnych struktur samorządowych, nawet bez współdzielenia $z$ nimi uprawnień do ostatecznego i formalnego podejmowania decyzji, zwyczajnie budzi niechęćczęści środowiska. Niekażdy dostrzega problem w stricte arbitralnym, eksperckim, a tym samym skrajnie subiektywnym systemie zarządzania dziedzictwem (Stawasz, \& Sikora-Fernandez, 2016). Jest to sytuacja o tyle problematyczna, że jednym z podstawowych założeń bardzo popularnego obecnie projektowania partycypacyjnego jest współpraca zróżnicowanych partnerów, a hasło zrównoważonego rozwoju można napotkać w niemal każdym dokumencie planistycznym na poziomie gminy, województwa i kraju.

\subsection{Edukacja i promocja opieki nad zabytkami}

Patrząc na zainteresowanie wolontariuszy testami przeprowadzonymi dotychczas na Politechnice Wrocławskiej, eye tracking mógłby być istotnym element działań promocyjnych prowadzonych zarówno na rzecz ochrony zabytków, jak i często niezauważanych i niedocenianych grup zawodowych zajmujących się opieką nad dziedzictwem kultury (French, 2011). Propagowano by uczestnictwo w konsultacjach społecznych. Jest to ważne, gdyż w Polsce zaangażowanie obywatelskie jest stosunkowo niewielkie, aż $2 / 3$ mieszkańców pozostaje poza sferą tego typu działań (Grabowska, Szczawiel, 2001), co jest w dużej mierze pokłosiem powojennej kondycji ekonomicznej państwa, jak i autorytarnego sposobu sprawowania władzy w okresie PRL (Tarkowscy, 1994). Być może eye tracking dałby również impuls do wypracowania nowych zrównoważonych i oddolnie ukierunkowanych sposobów wykorzystania dziedzictwa.

\subsection{Urzędy}

Proponowana modyfikacja z pewnością wymagałaby wprowadzania licznych zmian legislacyjnych $\mathrm{w}$ powiązanych dokumentach. Wiele aspektów takiej modyfikacji prawa trudno przewidzieć z wyprzedzeniem, co mogłoby zaowocować bardzo chaotycznym okresem przejściowym, a także trudnymi do uprzedniego zmierzenia konsekwencjami. Niezwykle trudno byłoby na przykład oszacować, jak duże opóźnianie w wydawaniu decyzji administracyjnych należałoby przewidzieć, aby umożliwić wykonanie takiego badania - zgłaszane sprawy posiadałyby przecież różny stopień skomplikowania. Ponadto w Polsce nie ma na chwilę obecną wystarczająco rozwiniętego prywatnego sektora badań okulograficznych, aby zapewnił on stabilne wsparcie. Tymczasem powierzanie podobnego zadania pracownikom urzędów mogłoby być niekorzystne, gdyż to oni często mogą okazać się jedną ze stron prowadzonego sporu. Badania powinny być zlecane niezależnej jednostce badawczej spoza regionu lub ponadregionalnym organizacjom społecznym o ugruntowanej tradycji, co zapewniłoby efektywność i bezstronność (Bogucka, 2001). 
Samo wdrożenie nowej formy kontroli byłoby kolejnym obciążeniem dla pracowników urzędów, którzy już teraz uskarżają się na dużą liczbę spraw do rozpoznania. To oni musieliby kierować konkretne projekty do kontroli okulograficznej, wypełniać formularze, redagować pisma i przestrzegać kolejnych procedur. Dodatkową trudnością byłoby to iż niedoświadczeni tej kwestii urzędnicy wymagaliby licznych - i relatywnie kosztownych - szkoleń.

Być może któryś $\mathrm{z}$ urzędów zgodziłby się $\mathrm{w}$ najbliższym czasie na wykonanie programu pilotażowego, który zweryfikowałby przydatność takiej metody w praktyce.

\subsection{Koszty}

Obawy może budzić również aspekt finansowy, gdyż przygotowanie, zbieranie danych, obróbka i ich interpretacja jest obecnie kosztowna. Prawdopodobnie nie zabraknie takich, zdaniem których lepiej byłoby wydać te kwoty na realne działania. Kontrargumentem jest jednak to, iż niekorzystne jest wydawanie pieniędzy na czynności budzące wątpliwości, potencjalnie mogące szkodzić miejscom objętym opieką. Kolejnym powodem przemawiającym za wspomaganiem zarządzania zbytkami przy pomocy okulografów, mogą okazać się tendencje rządzące rynkiem sprzedaży eye-trackerów. Obecnie zakup wideookulografu stacjonarnego wraz z oprogramowaniem to kwota rzędu 50-200 tysięcy złotych. Przewiduje się, że ich ceny w przeciągu 10-15 lat znacząco zmaleją, dlatego koszt zakupu urządzeń i oprogramowania przestanie być tak istotnym czynnikiem. Istnieje też realna możliwość, że urządzenia osobiste jak smartfony czy laptopy za jakiś czas będą posiadały moduły umożliwiające bezdotykową obsługę wzrokową, a wtedy automatycznie koszt i czasochłonność takich badań znacząco by spadły, umożliwiając samym badaniom stanie się zjawiskiem powszechnym.

Z drugiej strony w niektórych przypadkach zastosowanie okulografii mogłoby przynieść realne zyski. Wiele instytucji, na przykład muzeów, funkcjonuje w obiektach zabytkowych. Badania okulograficzne przeprowadzone na etapie tworzenia konsultowanej z konserwatorem koncepcji, mogłyby wskazać miejsca wymagające dłuższej refleksji np. nad lokalizacją nowego wejścia do obiektu, formy logo etc. Badania okulograficzne mogłyby też zwiększyć bezpieczeństwo użytkowników zabytkowych gmachów pozwalając np. na obiektywizację lokalizacji i rodzaju znaków wskazujących kierunek ewakuacji. Dzięki okulografom można by było pracować nad bardziej funkcjonalnymi rozwiązaniami i skutecznymi formami promocji zabytków, co miałoby szansę bezpośrednio przełożyć się na korzyści finansowe.

\subsection{Tradycjonaliści i innowatorzy}

Część architektów może postrzegać takie testy jako kolejne narzędzie ograniczające innowacyjność i rozwój architektury współczesnej lub ingerujące w przysługujące im prawa autorskie. Należy jednak pamiętać, że wykorzystanie okulografów mogłoby działać również na ich korzyść, gdy przeciwna ich zamiarom decyzja urzędnicza spotkałaby się z negatywną reakcją ze strony badanych. Testy okulograficzne nie mają na celu zamykać, lecz otwierać pole do interdyscyplinarnej dyskusji. Mogłyby służyć wypracowaniu rozwiązania optymalnego dla inwestora, architekta i społeczeństwa - najczęściej reprezentowanego przez urzędników. 
W ostateczności, gdy zalecenia konserwatorskie mogą być wynikiem „kreatywnej i zbyt daleko idącej działalności urzędników" (Filipowicz, 2010), okulograf byłby obiektywnym narzędziem protestu.

\subsection{Trwałość}

Ważną kwestią jest również to, czy wytyczne okulograficzne byłyby trwałe. Nie wiemy, w jakim tempie - między innymi pod wpływem zmieniającej się edukacji, dostępu do mediów, reklamy, ulegającym ewolucji teoriom i modom - będą się zmieniać wizualne oczekiwania społeczeństwa. Czy każdy zapis dotyczący ochrony wizualnej zabytku będzie na tyle uniwersalny, aby badania przeprowadzone przykładowo po 10 latach od momentu ustanowienia danego dalej miały sens? Ponadto zmieniająca się dynamicznie technologia okulograficzna może szybko uniemożliwiać przeprowadzenie analiz na pierwotnych warunkach - na przykład istnieje czysto teoretycznie możliwość, że nikt nie będzie w przyszłości produkował okulografu i oprogramowania, które pobiera dane z częstotliwością $120 \mathrm{~Hz}$.

\section{Zestawienie zalet i wad wynikających $\mathrm{z}$ potencjalnego wprowadzenia eye trackera do procesu zarządzania dziedzictwem architektury i urbanistyki}

\begin{tabular}{|c|c|}
\hline Zalety & Wady \\
\hline \multicolumn{2}{|l|}{ Badania } \\
\hline $\begin{array}{l}\text { - do przeprowadzenia badań potrzebne jest wyłącznie } \\
\text { niewielkie pomieszczenie; } \\
\text { - doświadczenia wskazują, iż szybko werbuje się } \\
\text { uczestników testów; } \\
\text { - dość łatwy sposób przygotowania bodźców 2D; } \\
\text { - bezpieczny i bezinwazyjny przebieg testów. }\end{array}$ & $\begin{array}{l}\text { - brak wystarczająco rozwiniętego sektora badań } \\
\text { okulograficznych w Polsce; } \\
\text { - konieczność każdorazowego weryfikowania trafności } \\
\text { metodologii badawczej; } \\
\text { - skomplikowany sposób przygotowania bodźców } \\
\text { sferycznych (3D). }\end{array}$ \\
\hline \multicolumn{2}{|l|}{ Koszty } \\
\hline $\begin{array}{l}\text { - sprzęt wykorzystywany jest wielokrotnie; } \\
\text { - badania, jeśli tylko mają podobną metodologię, można } \\
\text { prowadzić na tych samych grupach badawczych; } \\
\text { - przewiduje się, iż cena urządzeń będzie malała. }\end{array}$ & $\begin{array}{l}\text { - konieczność zakupu drogiej aparatury; } \\
\text { - konieczność opłacania uczestników badań, grupa } \\
\text { badawcza musi być odpowiednio duża; } \\
\text { - wykorzystywanie funduszy nie na realne działania. }\end{array}$ \\
\hline \multicolumn{2}{|l|}{ Wyniki tetsów } \\
\hline $\begin{array}{l}\text { - mają postać numeryczną, którą można w różny } \\
\text { sposób prezentować; } \\
\text { - są obiektywne, gdy będą wykonane przez } \\
\text { doświadczoną jednostkę badawczą spoza regionu. }\end{array}$ & - trudno określić, jak długo wyniki będą aktualne. \\
\hline
\end{tabular}




\section{Marta Alina Rusnak}

\section{Regulacje prawne i postępowanie administracyjne}

- możliwość forowania jednoznacznych zapisów prawa np. w odniesieniu do ochrony krajobrazu, ochrony przeciwpożarowej zabytków;

- możliwość łatwego udowodnienia swoich racji przed sądem (dotyczy to zarówno inwestorów i urzędników, jak i organizacji społecznych).
- konieczność wprowadzenia modyfikacji prawa; - nie wiadomo jak duże opóźnienie w wydawaniu opinii administracyjnych spowodowałoby wprowadzenie tych badań np. do procesu uzyskiwania pozwolenia na budowę;
- dodatkowe koszty postępowania;
- brak doświadczenia np. rzeczoznawców.

\section{Wszyscy uczestnicy procesu opieki nad zabytkami i zarządzania dziedzictwem}

\begin{tabular}{|l|lll}
\hline - zyskanie nowej możliwości weryfikacji rzeczywistego & - brak doświadczenia; & & \\
wpływu proponowanej zmiany na widza; & - czasochłonna konieczność zapoznania się z nowym \\
- uczestnicy procesu zarządzania dziedzictwem zyskują & narzędziem i procedurami; \\
wspólny punkt odniesienia w czasie negocjacji. & $\begin{array}{l}\text { konieczność aktualizacji wiedzy } \\
\text { technologiach okulograficznych. }\end{array}$ & \\
\hline
\end{tabular}

\section{Projektanci}

- możliwość wykonywania projektów, by świadomie kierować uwagą obserwatorów;

- kolejne ograniczenia „swobody wyrazu artystycznego”; - mają doświadczenie w obsłudze programów graficznych - łatwo będą w stanie przygotować bodźce do eksperymentu.

\section{Urzędnicy}

- argument ułatwiający mediacyjne rozwiązywania sytuacji konfliktowych np. z inwestorami czy politykami; - możliwość kierowania procesem doboru badanych opcji;

- dodatkowe obowiązki i procedury;

- konieczność spisania wytycznych do eksperymentów.

- zyskanie wiedzy o tym, które aspekty swoich decyzji należy najlepiej uzasadnić społeczeństwu.

\section{Konserwatorzy}

- nabywanie i weryfikacja wiedzy;

- możliwość łatwego badania wariantów;

- możliwość kierowania procesem doboru badanych opcji; - strach o utratę „autorytetu”;

- możliwość poznania taktyk zarządzania dziedzictwem - możliwość promowania rozwiązań w „złym guście”.

dopasowanych do potrzeb konkretnego zabytku i grupy użytkowników.

\section{Inwestorzy}

- możliwość weryfikowania skuteczności proponowanych rozwiązań wizualnych, marketing; - możliwe wydłużenie czasu, w jakim uzyskuje się - możliwość odwołania się, udowodnienia swojej racji opinie administracyjne.

w przypadku nadużyć urzędniczych.

\section{Społeczeństwo}

- promocja opieki nad zabytkami;

- demokratyczne urzeczywistnienie konsultacji - relatywnie mała aktywność Polaków w sferze społecznych, których wyniki łatwo przełożyć na konsultacji społecznych.

aspekty projektowe. 


\section{Podsumowanie}

Pomimo wielu wątpliwości wyrażonych $\mathrm{w}$ artykule, wierzę, iż okulograf może stanowić cenne narzędzie służące obiektywizacji i uspołecznieniu procesu ochrony zabytków. Część wymienionych w powyższym bilansie wad zniknęłaby wraz z rozwojem tego sektora badawczego i oswojeniem się uczestników procesu zarządzania dziedzictwem $z$ nową technologią. To przyrząd, który ma szansę wspierać i inicjować dialog pomiędzy różnymi grupami społecznymi, a odnoszący się do przestrzeni urbanistycznej i dziedzictwa historii. Wreszcie dzięki eye trackerom uzgodnienia ekspertów z różnych dziedzin mogłyby w końcu zyskać istotny, obiektywny i wspólny punkt odniesienia. 


\section{Marta Alina Rusnak}

\section{Bibliografia}

Bogucka T., (7.09.2001) Państwowe czy społeczne, Gazeta Wyborcza.

Chhabra D., (2015) Sustainable Marketing of Cultural and Heritage Tourism, London/New York, Routledge.

Chun S. A., \& Artigas F. (2015). Participatory Enviroment Planing Platform, [w:] Emerging Issues, Challanges, and Oportunieties in Urban E-Planing, s. 46-68, Hershey: IGI Global.

Duchowski A.T., (2017) Eye Tracking Methodology: Theory and Practice, Springer.

"Fatamorgana" czy ciekawa realizacja? Kontrowersje wokół Biblioteki Archidiecezjalnej na Ostrowie Tumskim, Gazeta Wyborcza, (3.05.2016), http://wroclaw.wyborcza.pl/wroclaw/1,357

71,20071236,fatamorgana-czy-ciekawa-realizacja-kontrowersje-wokol-biblioteki.html, dostęp 05.12.2019.

Filipowicz P., (2010), Rola zaleceń konserwatorskich $w$ procesie inwestycyjnym realizowanym w obiekcie zabytkowym w świetle oczekiwań projektanta i inwestora, [w:] Kurier Konserwatorski, s. 6-10.

French Y., (2011), Marketing and Public Relations for Museums, Galleries, Cultural and Heritage Attractions, Londyn, Routelege.

Gołaszewska M., (1984), Zarys estetyki. Problematyka, metody, teorie, Warszawa: Państwowe Wydawnictwo Naukowe.

Gombrich E., (1979) The Sense of Order. a Study in the Psychology of Decorative Art. Oxford: Phaidon.

Grabowska M., Pancewicz Ł., Sagan I., (2015), The Impact of Information and Comunication Technology on the Rise of Urban Social Moovements in Poland, [w:] Emerging Issues, Challanges, and Oportunieties in Urban E-Planing. (s. 93-113): Hershey: IGI Global.

Grabowska M., Szczawiel T., (2001), Budowanie demokracji, Warszawa, PWN.

Holmqvist K., Noström M., Anderson R., Delvurst R, Jarodzka H., van de Weijer J., (2011), Eyetracking. Acomprehansive guide to methods and measures. Oxford: Oxford University Press.

Ingarden R., (1970), Czego nie wiemy o wartościach, [w:] Studia z estetyki, T. 3, s. 220-257.

Kłosek-Kozłowska D., (2017), Ochrona wartości kulturowych miast a urbanistyka, (148): Warszawa: Politechnika Warszawska.

Lubocka-Hoffmann M., (2000), Retrowersja - konserwatorska metoda odbudowy miasta historycznego, [w:] Problemy zarzadzania dziedzictwem kulturowym, (s. 192-209): Warszawa: Politechnika Warszawska.

Mager T., (2015), Architecture RePerformed. The Polithics of Reconstruction, London/New York: Routledge.

Murzyn M., (2014), Subiektywizm i obiektywizm aksjologiczny podstawa rozdzielenia zadań w systemie ochrony zabytków i zarzadzaniu dziedzictwem kulturowym, [w:] Wartość funkcji w obiektach zabytkowych, (s. 195-204): Warszawa: PKICOMOS/Pałac w Wilanowie. 
Parowicz I., (2018), Cultural Heritage Marketing: A Relationship Marketing Approach to Conservation Services, Palgrave Pivot.

Rusnak M., Fikus W., Szewczyk J., (2018), Jak obserwatorzy postrzegaja głębię we wnętrzu gotyckiej katedry wraz ze zmiana jej proporcji? Sondaż okulograficzny, Architectus, 1(53), s. 7788. DOI:10.5277/arc18010.

Rusnak M., Ramus E., (2019), With an eye tracker at the Warsaw Rising Museum: valorization of historical interiors, [w:] Journal of Heritage Cnservation., 59, s. 78-90, DOI:10.17425/ WK58WARSAW.

Rusnak M., Szewczyk J. (2018), Eye trackers in evaluation of transformation of historical monuments. Revitalisation of the Dresden arsenal, [w:] E3S Web of Conferences49,00093, DOI. org/10.1051/e3sconf/20184900092.

Rusnak M., Szewczyk J., (2018), Eye tracker as an innovative conservation tool. Ideas for expanding rang of reserch related to architectural and Urban heritage, [w:] Journal of Heritage Conservation; 54, s. 25-35, DOI:10.17425/WK54EYETRACK

Soluch P., Tarnowski A., (2013), O metodologii badań eyetrackingowych, [w:] Lingwistyka stosowana, 7, s. 115-134.

Stawasz D., Sikora-Fernandez D., (2016), Koncepcja smart city na tle procesów i uwarunkowań rozwoju wspótczesnych miast. (29): Łódź: Uniwersytet Łódzki.

Tarkowska E., Tarkowski J., (1994), Amoralny familiom, czyli o dezintegracji społecznej w Polsce lat osiemdziesiatych, [w:] Socjologia świata polityki, T. I. Władza i społeczeństwo w systemie autorytarnym, (s. 263-281) Warszawa: ISP PAN.

Uchwała NR XIIT/442/99 Rady Miejskiej Wrocławia dnia 21 października 1999 roku w sprawie uchwalenia miejscowego planu zagospodarowania przestrzennego obszaru - Ostrów Tumski, wyspy i Ogród Botaniczny we Wrocławiu. 